Georgetown University Law Center

Scholarship @ GEORGETOWN LAW

2003

\title{
The Original Meaning of the Necessary and Proper Clause
}

Randy E. Barnett

Georgetown University Law Center, rb325@law.georgetown.edu

This paper can be downloaded free of charge from:

https://scholarship.law.georgetown.edu/facpub/45

6 U. PA. J. Const. L. 183-221 (2003)

This open-access article is brought to you by the Georgetown Law Library. Posted with permission of the author. Follow this and additional works at: https://scholarship.law.georgetown.edu/facpub

Part of the Constitutional Law Commons 


\title{
GEORGETOWN LAW Faculty Publications
}

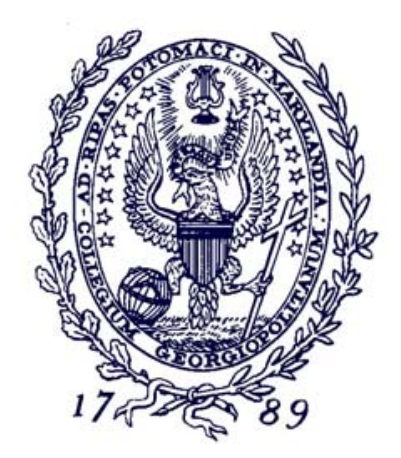

January 2010

\section{The Original Meaning of the Necessary and Proper Clause}

6 U. Pa. J. Const. L. 183-221 (2003)

\author{
Randy E. Barnett \\ Professor of Law \\ Georgetown University Law Center \\ rb325@law.georgetown.edu
}

This paper can be downloaded without charge from:

Scholarly Commons: http://scholarship.law.georgetown.edu/facpub/45/

SSRN: http://ssrn.com/abstract $=410542$

Posted with permission of the author 


\title{
ARTICLES \\ THE ORIGINAL MEANING OF THE NECESSARY AND PROPER CLAUSE
}

\begin{abstract}
Randy E. Bamett
Whatever meaning this clause may have, none can be admitted, that would give an unlimited discretion to Congress.

-James Madison
\end{abstract}

\section{INTRODUCTION}

In two articles, The Original Meaning of the Commerce Clause ${ }^{2}$ and New Evidence of the Original Meaning of the Commerce Clause, I presented evidence of the public meaning of Congress's power " $[t]$ o regulate Commerce with foreign Nations, and among the several States, and with the Indian Tribes." "Commerce" meant the trade or exchange of goods (including the means of transporting them); "among the several States" meant between persons of one state and another; and the term "[t]o regulate" meant "to make regular"-to specify how an activity may be transacted-when applied to domestic commerce, but also included the power to make "prohibitory regulations" when applied to foreign trade. ${ }^{5}$ In sum, Congress has power to specify rules to govern the manner by which people may exchange or trade goods from one state to another, to remove obstructions to domestic trade erected by states, and to both regulate and restrict the flow of goods to and from other nations (and the Indian tribes) for the purpose of promoting the domestic economy and foreign trade.

- Austin B. Fletcher Professor, Boston University School of Law (rbarnett@bu.edu). My thanks to Kate McFarland for her research assistance. Permission to photocopy for classroom use is hereby granted.

1 ANNALS OF CONG. 1947 (Joseph Gales ed., 1791) (Ed. Note: The Annals of the 1st Congress are particularly problematic in citing due to differing hard-to-find versions that often do not clearly delineate volume numbers. All citations to 1 ANNALS OF CONG. herein are to the Annals of the 1st Congress, 1789-1791, as edited by Joseph Gales and available on the Library of Congress's Web site at http://memory.loc.gov/ammem/amlaw/lwaclink.html).

${ }^{2}$ Randy E. Barnett, The Original Meaning of the Commerce Clause, 68 U. CHI. L. REv. 101 (2001) [hereinafter Barnett, Original Meaning].

${ }^{3}$ Randy E. Barnett, New Evidence of the Original Meaning of the Commerce Clause, 55 ARK. L. REv. 847 (2003) [hereinafter Barnett, New Evidence].

${ }^{4}$ U.S. CONST. art. I, $\$ 8$, cl. 3.

${ }^{5}$ Barnett, Original Meaning, supra note 2, at 101. 
To determine the constitutionality of any particular legislation and evaluate judicial applications of the Commerce Clause, we must also consider the meaning of the Necessary and Proper Clause. ${ }^{6}$ For, as has been noted by Stephen Gardbaum, the expansive post-New Deal reading of congressional power owes as much to the Supreme Court's interpretation of the Necessary and Proper Clause as it does to the Supreme Court's expansive reading of the Commerce Clause:

[T] he New Deal Court's own constitutional justification for its radical expansion of the scope of federal power over commerce was that the congressional measures in question were valid exercises of the power granted by the Necessary and Proper Clause and were not direct exercises of the power to regulate commerce among the several states. That is, the Court did not simply and directly enlarge the scope of the Commerce Clause itself, as is often believed. Rather, it upheld various federal enactments as necessary and proper means to achieve the legitimate objective of regulating interstate commerce.

In this Article, I present the evidence of the original public meaning of the Necessary and Proper Clause. ${ }^{8}$ These findings will, of course, be of interest to originalists. But, they should also be of interest to the many constitutional scholars who consider original meaning to be one among several legitimate modes of constitutional analysis," or who consider original meaning the starting point of a process by which this meaning is translated into contemporary terms. $^{10}$ By either account, it is important to find the correct original meaning, even if it is not dispositive of today's cases and controversies.

I will show that the choice between the meanings of "necessary" inherited from John Marshall's discussion in McCulloch v. Maryland" - that of "indispensably requisite" on the one hand and merely "convenient" on the other-is undercut by the available evidence. Rather, the truth lies somewhere in between.

${ }^{6}$ U.S. CONST, art. I, $\$ 8$, cl. 18.

${ }^{7}$ Stephen Gardbaum, Rethinking Constitutional Federalism, 74 TEX. L. REV. 795, 807-08 (1996) (footnotes omitted).

"I distinguish between an originalism based on "original meaning" and an originalism based on "original intent." See Barnett, Original Meaning, supra note 2, at 105-08. For my initial explication and defense of original meaning originalism, see Randy E. Barnett, An Originalism for Nonoriginalists, 45 LOY. L. REV. 611 (1999). I will be expanding my defense of originalism as a vital means of enhancing constitutional legitimacy in RANDY E. BARNETT, RESTORING THE LOST CONSTItUTION: The PRESUMPTION OF LiberTy (forthcoming February 2004).

9 See, e.g., Philip BobBITT, CONSTITUTIONAL INTERPRETATION 13-14 (1991) (counting both "historical" and "textual" as useful and legitimate "modalities" of constitutional argument).

${ }^{10}$ See, e.g., Iawrence Lessig, Fidelity in Translation, 71 TEX. L. REV. 1165 (1993) (proposing a method of interpretation that translates original meaning into present day circumstances).

1117 U.S. (4 Wheat.) 316,367 (1819).

${ }^{12}$ This Article represents a change in my position from that which I expressed in Randy $\mathrm{E}$ Barnett, Necessary and Proper, 44 UCLA L. REV. 745 (1997), an article written before I had 


\section{The ORIGiN OF THE NeCESSARY AND PROPER ClaUSE}

The Necessary and Proper Clause was added to the Constitution by the Committee on Detail without any previous discussion by the Constitutional Convention. Nor was it the subject of any debate from its initial proposal to the Convention's final adoption of the Constitution. ${ }^{13}$ One thing we do know about its legislative history is the wording of a clause that was earlier proposed by Gunning Bedford and rejected by the Committee. The proposal was that Congress have the power "to legislate in all cases for the general interests of the Union, and also in those to which the States are separately incompetent, or in which the harmony of the United States may be interrupted by the exercise of individual Legislation." ${ }^{\text {14 }}$ In other words, the Convention had before it an almost completely open-ended grant of power to Congress and rejected it, without discussion, in favor of the enumeration of particular powers and the ancillary Necessary and Proper Clause.

The likely reason why the Necessary and Proper Clause received no attention by the Convention became clear during the debates in the ratification conventions, as did its public meaning. There, opponents of the Constitution pointed to this power as evidence that the national government had unlimited and undefined powers. In the New York Convention, for example, John Williams contended that it "is perhaps utterly impossible fully to define this power." ${ }^{15}$ For this reason, " $[w]$ hatever they judge necessary for the proper administration of the powers lodged in them, they may execute without any check or impediment."

Meanwhile, Federalist supporters of the Constitution repeatedly denied the charge that Congress had discretion in defining the scope of its own powers. They insisted that the Necessary and Proper Clause was not an additional freestanding grant of power, but merely made explicit what was already implicit in the grant of each enumerated power. As explained by George Nicholas to the Virginia Convention, "the Constitution had enumerated all the powers which the

adopted an originalist methodology and examined much of the additional evidence of original meaning presented here.

19 The only time it was considered was when Madison and Charles Pinckney proposed that it be modified by inserting the phrase "and establish all offices" because it appeared to them that this power might be questioned. Their proposal was rejected without discussion by a vote of 9 to 2. JAMES MAdison, NOTES OF DEBATES IN THE FEDERAL CONVENTION Of 1787, at 489 (W.W. Norton \& Co. 1987) (1893).

${ }^{14}$ Id. at 303.

${ }^{15} 2$ The Debates in the Several State Conventions on the Adoption of the Federal Constitution, as Recommended by the General Convention at Philadelphia, in 1787, at 331 (Jonathan Elliot ed., rev. 2d ed. 1941) (1836) [hereinafter Debates].

${ }^{16} I d$. at 338. 
general government should have, but did not say how they were to be exercised. It therefore, in this clause, tells how they shall be exercised." Like other Federalists, Nicholas denied that this Clause gave "any new power" to Congress. "Suppose," he reasoned:

it had been inserted, at the end of every power, that they should have power to make laws to carry that power into execution; would this have increased their powers? If, therefore, it could not have increased their powers, if placed at the end of each power, it cannot increase them at the end of all. ${ }^{\text {p }}$

In short, " $[t]$ his clause only enables them to carry into execution the powers given to them, but gives them no additional power." ${ }^{19}$ Madison added his voice to the chorus: "the sweeping clause ... only extended to the enumerated powers. Should Congress attempt to extend it to any power not enumerated, it would not be warranted by the clause."

Also in Virginia, Edmund Pendleton, president of the Convention, insisted that this Clause did not go, "a single step beyond the delegated powers." ${ }^{21}$

If [Congress were] about to pass a law in consequence of this clause, they must pursue some of the delegated powers, but can by no means depart from them, or arrogate any new powers; for the plain language of the clause is, to give them power to pass laws in order to give effect to the delegated powers. ${ }^{22}$

The same point was made in the North Carolina Convention: "This clause specifies that they shall make laws to carry into execution all the powers vested by this Constitution; consequently, they can make no laws to execute any other power. This clause gives no new power, but declares that those already given are to be executed by proper laws." In Pennsylvania, James Wilson explained that this Clause "is saying no more than that the powers we have already particularly given, shall be effectually carried into execution." ${ }^{24}$ And Thomas M'Kean insisted that "it gives to Congress no further powers than those already enumerated."

Here, then, is the likely explanation for the lack of debate surrounding the Clause at the Philadelphia Convention: if the power to make law was already thought implicit in the enumerated powers

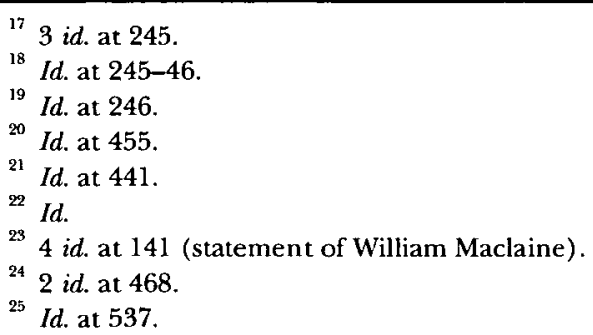


scheme, then it is not surprising that the Clause would provoke no discussion at the Convention. Joseph Lynch offers a different explanation for the silence of the Convention. He suggests that the wording of the Clause was made deliberately ambiguous so that both sides could later argue for their favored interpretation. Nationalists from the Northern and Atlantic states could argue that the Clause was equivalent to the rejected Bedford Proposal, while the Southern and rural federalists could argue that Congress was limited to enacting laws that were incidental to the enumerated powers. The silent reception of the Clause by all sides, he claims, reflected their unwillingness to tamper with the compromise represented by this ambiguity. According to Lynch, " $[\mathrm{t}]$ he ambiguity of the language that the committee proposed and that the convention approved enabled both sides not only to approve its inclusion in the Constitution but also to argue afterwards that their construction was in accord with the framers' intent." ${ }^{26}$

Although the circumstantial evidence he offers on behalf of this theory is intriguing, it generally relates to the subjective original intent of the framers, not to the original meaning that the Clause would have had to a reasonable person at the time of founding. According to original-meaning originalism, secret intentions are not binding. ${ }^{27}$ The issue is what interpretation best reflects the publicly accessible meaning of the Clause.

Moreover, any ambiguity in the wording was clarified by the Federalists' public insistence during the ratification that the Clause only authorized the enactment of laws that were incidental to the enumerated powers, and that this power would have been inherent to the enumerated powers had there been no Necessary and Proper Clause at the end of the list. In the conventions, we know of no disagreement as to the meaning of the Clause expressed by supporters of the Constitution. All denied it was the equivalent of the Bedford Proposal. Professor Lynch concedes as much when he observes:

Whatever private understandings the framers may have had among themselves-that proponents of a strong national government could be free to argue, for instance, that the Necessary and Proper Clause included an undefined bevy of congressional and presidential powers...-the supporters of the Constitution had for the most part publicly disavowed

${ }^{26}$ Joseph M. Lynch, Negotiating the Constitution: THE EARLiest Debates over Original InTENT 25 (1999). I think Professor Lynch is correct to use the term "ambiguity," rather than vagueness for, as we shall see, at issue here is which of two possible meanings of "necessity" was the meaning conveyed by the term "necessary."

${ }^{27}$ See Barnett, An Originalism for Nonoriginalists, supra note 8, at 620-29 (distinguishing original meaning interpretation from that based on original intent, and defending the former). 
avowed such understandings both in the Federalist and in the state conventions in their campaign to secure ratification. ${ }^{28}$

Such public utterances during ratification clarify what the original public meaning of a term was, and it is that public meaning to which I now turn.

\section{THE MEANING OF "NECESSARY"}

Despite the uniform denials by the Constitution's advocates that the Necessary and Proper Clause expanded the powers of the national government, a national bank was proposed to the Federalistdominated first Congress by Secretary of the Treasury Alexander Hamilton. There ensued the most hotly contested constitutional conflict of the early years of the Constitution. ${ }^{29}$ Official opinions on the subject were issued by Attorney General Edmund Randolph, Secretary of State Thomas Jefferson, and Hamilton. Of these, Randolph and Jefferson argued against its constitutionality, with Hamilton arguing in favor. Among the leaders in the House who contended that the bank was unconstitutional was James Madison. The ambiguity of the term "necessary" was quickly revealed by this controversy, requiring us to decide which meaning was the original one. ${ }^{30}$

\section{A. "Necessary" Means Really Necessary: Madison, Jefferson Ẽ Randolph}

The opening salvo on the constitutionality of the proposed bank was fired by James Madison, who was serving as a member of the first Congress, when on February 2, 1791, he delivered a lengthy speech on the merits of the bank bill. His speech began with "a general review of the advantages and disadvantages of Banks,"31 but in making these remarks "he had reserved to himself the right to deny the authority of Congress to pass it." 32

Before addressing the constitutionality of the bill, he first provided a list of principles that should guide constitutional interpretation and construction:

An interpretation that destroys the very characteristic of the Government cannot be just.

Where a meaning is clear, the consequences, whatever they may be, are to be admitted - where doubtful, it is fairly triable by its consequences.

${ }^{28} \mathrm{LYNCH}$, supra note 26 , at 112.

${ }^{29}$ The Alien and Sedition Acts were not enacted until 1798.

${ }^{30}$ On the difference for originalist interpretation between textual ambiguity and vagueness, see Barnett, New Evidence, supra note 3, at 852-56.

11 1 ANNALS OF CONG. 1944 (Joseph Gales ed., 1791).

${ }^{32}$ Id. at 1945 . 
In controverted cases, the meaning of the parties to the instrument, if to be collected by reasonable evidence, is a proper guide.

Contemporary and concurrent expositions are a reasonable evidence of the meaning of the parties.

In admitting or rejecting a constructive authority, not only the degree of its incidentality to an express authority is to be regarded, but the degree of its importance also; since on this will depend the probability or improbability of its being left to construction. ${ }^{33}$

Notice that Madison implicitly distinguished between an explicit power (which is a matter of interpretation "where a meaning is clear") and one that is only implicit (and "left to construction"). Given that the power to establish a bank or issue charters of incorporation was not explicitly granted, and viewing the Constitution in light of these principles, Madison was led to conclude that "it was not possible to discover in it the power to incorporate a Bank." ${ }^{35}$

Madison thought this conclusion was compelled both by general principles of congressional power and by the specific powers being invoked on behalf of the bank. On general principle:

All power ... had its limits; those of the general government were ceded from the mass of general power inherent in the people, and were consequently confined within the bound fixed by their act of cession. The constitution was this act; and to warrant Congress in exercising the power, the grant of it should be pointed out in that instrument ....

In Madison's view, "this ... had not been done," and he "presumed it could not be done." When it came to constitutional construction, "such construction only was admissible as carefully preserved entire the idea on which that constitution is founded." ${ }^{38}$

Supporters of the bank had argued that it was justified as incidental to the power " $[\mathrm{t}] \mathrm{o}$ lay and collect Taxes, Duties, Imposts and Excises, to pay the Debts and provide for the common Defence and general Welfare of the United States" ${ }^{\text {"39 }}$ and the power " $[\mathrm{t}] \mathrm{o}$ borrow

s3 Id. at 1946.

34 See Keith E. Whittington, Constitutional Interpretation: Textual Meaning, ORIGINAL INTENT, AND JUDICIAL REVIEW 7 (1999) (distinguishing between interpretation and construction); KeIth E. WHITTINGTON, CONSTITUTIONAL CONSTRUCTION: Divided POWERS AND CONSTITUTIONAL MEANING 1-19 (1999) (discussing interpretation and construction, and arguing that construction is necessary to complement interpretation because constitutional interpretation cannot answer every constitutional question).

351 ANNALS OF CONG. 1946 (Joseph Gales ed., 1791).

${ }^{36} 14$ Documentary History OF THE First Federal Congress 4 MARCH 1789-3 March 1791, at 379 (William Charles DiGiacomantonio et al. eds., 1995). This passage is found in an article in The General Advertiser, February 7, 1791. It does not appear in the lengthier and otherwise more detailed report of Madison's speech included in the Annals of Congress, which was originally published in the Gazette of the United States, February 23, 1791.

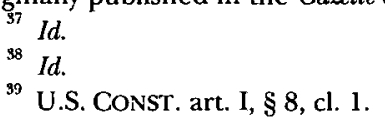


money on the credit of the United States. ${ }^{40}$ Madison noted that no argument could be based on the terms "provide for the common Defence and general Welfare of the United States," because these terms pertained only to the purpose for exercising the taxing power and these "general purposes themselves were limited and explained by the particular enumeration subjoined."

In other words, according to Madison, Congress could use taxes to provide for the common defense and general welfare only when exercising the other powers that were enumerated in Article I. The taxing power could not be used to pursue any end that might be thought conducive to the common defense or the general welfare. Why not? "To understand these terms in any sense, that would justify the power in question, would give to Congress an unlimited power; would render nugatory the enumeration of particular powers; would supersede all the powers reserved to the State Governments."

Madison noted that the terms "common defence" and "general welfare" had been "copied from the articles of Confederation" and asked rhetorically whether it had "ever been pretended, that they were to be understood otherwise than as here explained?"43 Nor could the bill be justified as a direct exercise of the borrowing power; "It does not borrow a shilling." If anything, it created the power to lend, not borrow.

Madison then turned his attention to the Necessary and Proper Clause. In a crucial passage of his speech he stated:

Whatever meaning this clause may have, none can be admitted, that would give an unlimited discretion to Congress.

Its meaning must, according to the natural and obvious force of the terms and the context, be limited to means necessary to the end, and incident to the nature of the specified powers.

The clause is in fact merely declaratory of what would have resulted by unavoidable implication, as the appropriate, and, as it were, technical means of executing those powers. In this sense it has been explained by the friends of the Constitution, and ratified by the State Conventions.

${ }^{40}$ Id., $\mathrm{cl} .2$.

41 1 ANNALS OF CONG. 1946 (Joseph Gales ed., 1791).

${ }^{42} I d$.

43 Id. The Articles of Confederation, Article VIII, had provided that "[a]ll charges of war, and all other expences that shall be incurred for the common defence or general welfare, and allowed by the united states in congress assembled, shall be defrayed out of a common treasury," and, in Article IX, that "The united states in congress assembled shall never . . ascertain the sums and expences necessary for the defence and welfare of the united states ... unless by the votes of a majority of the united states in congress assembled." In both instances, the terms "common defence" and "general welfare" qualified the spending power of Congress. It was not a free standing power of its own.

41 ANNALS OF CONG. 1947 (Joseph Gales ed., 1791). 
The essential characteristic of the Government, as composed of limited and enumerated powers, would be destroyed, if instead of direct and incidental means, any means could be used which, in the language of the preamble to the bill, "might be conceived to be conducive to the successful conducting of the finances, or might be conceived to tend to give facility to the obtaining of loans." 45

Distinguishing between interpretation and construction, Madison noted "the diffusive and ductile interpretation of these words and the boundless latitude of construction given them by the friends of the bank." He contended "that by their construction" of the Necessary and Proper Clause "every possible power might be exercised. The government would then be paramount in all possible cases ... and every limitation effectually swept away." trine of implication, he warned the friends to this system, was a dangerous one."

Madison thought that trying to justify the constitutionality of a national bank as necessary for carrying into execution an enumerated power required too great a stretch:

Mark the reasoning on which the validity of the bill depends. To borrow money is made the end, and the accumulation of capitals implied as the means. The accumulation of capitals is then the end, and a Bank implied as the means. The Bank is then the end, and a charter of incorporation, a monopoly, capital punishments, \&cc. implied as the means.

If implications, thus remote and thus multiplied, can be linked together, a chain may be formed that will reach every object of legislation, every object within the whole compass of political economy.

Nine years later, in discussing another claim of power by Congress, Jefferson as president would compare this style of argument to the child's game "This is the House that Jack Built."

Madison gave several examples of enumerated powers that were not left to implication, though if a latitudinarian interpretation of the

${ }^{45} I d$. at 1947-48 (emphasis added).

46 Documentary History of THE First Federal Congress 4 March 1789-3 March 1791, supra note 36 , at 380 .

${ }^{47}$ Id.

${ }^{48} I d$.

491 ANNALS OF CONG. 1948-49 (Joseph Gales ed., 1791).

${ }^{50}$ In criticizing a House bill incorporating a company for the Roosevelt copper mines in New Jersey, President Jefferson observed that its supporters justified its constitutionality under the sweeping clause of the Constitution by offering the following pedigree of necessities:

Congress are authorized to defend the nation. Ships are necessary for defence; copper is necessary for ships; mines necessary for copper; a company necessary to work mines; and who can doubt this reasoning who has ever played at "This is the House that Jack Built?"

Under such a process of filiation of necessities the sweeping clause makes clean work.

Letter from Thomas Jefferson to Edward Livingston (Apr. 30, 1800), in 10 THE WRITINGS OF THOMAS JefFERSON 165 (Andrew A. Lipscomb \& Albert E. Bergh eds., memorial ed. 1903). 
Necessary and Proper Clause were correct, they surely could have been.

Congress have power "to regulate the value of money;" yet it is expressly added, not left to be implied, that counterfeiters may be punished.

They have the power "to declare war," to which armies are more incident, than incorporated banks to borrowing; yet the power "to raise and support armies" is expressly added; and to this again, the express power "to make rules and regulations for the government of armies;" a like remark is applicable to the powers as to the navy.

The regulation and calling out of the militia are more appurtenant to war than the proposed Bank to borrowing; yet the former is not left to construction.

The very power to borrow money is a less remote implication from the power of war, than an incorporated monopoly Bank from the power of borrowing; yet, the power to borrow is not left to implication. ${ }^{51}$

Madison did not mean to exaggerate the significance of these sorts of drafting decisions: "It is not pretended that every insertion or omission in the Constitution is the effect of systematic attention. This is not the character of any human work, particularly the work of a body of men." ${ }^{\text {"22 }}$ Yet he thought that these examples "with others that might be added, sufficiently inculcate, nevertheless, a rule of interpretation very different from that on which the bill rests. They condemn the exercise of any power, particularly a great and important power, which is not evidently and necessarily involved in an express power." ${ }^{53}$

Madison offered a distinction "which he said had not been sufficiently kept in view." This is the distinction between (a) a power that is "necessary and proper for the Government or Union" and (b) a power that is, "necessary and proper for executing the enumerated powers. ${ }^{, 56}$ The only powers that are necessary and proper for the national government are those that were enumerated; the only proper unenumerated powers are those derived from the nature of a power that was expressed.

[This expression of particular powers (and no others)] constituted the peculiar nature of the Government, no power, therefore, not enumerated could be inferred from the general nature of Government. Had the power of making treaties, for example, been omitted, however necessary

\footnotetext{
51 ANNALS OF CONG. 1949 (Joseph Gales ed., 1791).

${ }^{52}$ Id.

${ }^{53}$ Id.

${ }^{54} I d$. at 1950.

${ }^{55} \mathrm{Id}$.

${ }^{56} I d$.
} 
it might have been, the defect could only have been lamented, or supplied by an amendment of the Constitution. ${ }^{57}$

Madison then offered the crucial distinction between "necessity" and "convenience." "But the proposed Bank could not even be called necessary to the Government; at most it could be but convenient." 58 There were many other ways, short of exercising this power to incorporate a bank, for the government to accomplish its enumerated objects or end.

Madison read portions of the ratification debates in which critics of the Constitution seized upon the Necessary and Proper Clause as evidence of the "dangerous latitude of its powers" and its supporters argued that this Clause was to be interpreted as Madison had just done before Congress.

The defence against the charge founded on the want of a bill of rights pre-supposed, he said, that the powers not given were retained; and that those given were not to be extended by remote implications. On any other supposition, the power of Congress to abridge the freedom of the press, or the rights of conscience, \&c. could not have been disproved.

The explanations in the State Conventions all turned on the same fundamental principle, and on the principle that the terms necessary and proper gave no additional powers to those enumerated. ${ }^{60}$

As was shown above, the record bears out Madison's characterization.

Madison also made a crucial connection between the Necessary and Proper Clause and the protection of the rights retained by and powers reserved to the people by citing the Ninth and Tenth Amendments in support of this "rule of interpretation." Of course, in February of 1791, these amendments had yet to be ratified, and on that date were the eleventh and twelfth on the list of amendments then pending before states. Perhaps because he referred to them by these numbers, this use by Madison in a constitutional argument of the Ninth Amendment, which he himself had devised, had, until recently, largely been ignored. "The latitude of interpretation required by the bill is condemned by the rule furnished by the Constitution itself." As authority for this rule he offered this:

The explanatory amendments proposed by Congress themselves, at least, would be good authority with them; all these renunciations of power proceeded on a rule of construction, excluding the latitude now contended for .... He read several of the articles proposed, remarking particularly on the 11th [the Ninth Amendment] and 12th [the Tenth

\footnotetext{
${ }^{57}$ Id.

${ }^{58} I d$.

${ }^{59} I d$. at 1951 .

60) Id.

${ }^{61}$ Id. at 1949.
} 
Amendment], the former, as guarding against a latitude of interpretation; the latter, as excluding every source of power not within the Constitution itself. ${ }^{62}$

Thus, for Madison, whether or not a proposed action of government that restricted the liberty of the people was necessary, and therefore within the powers of Congress to enact, required some assessment of whether the means chosen were essential to the pursuit of an enumerated end. Without this assessment, the scheme of limited enumerated powers would unravel. In his words, allowing the exercise of a power that was neither specifically enumerated, nor fairly inferred from one that is, "involves the guilt of usurpation, and establishes a precedent of interpretation, levelling all the barriers which limit the powers of the General Government."

In Congress, Madison was joined by Representative Michael Stone of Maryland, a lawyer by training, who argued forcefully against the doctrine of implied powers which he characterized "as a serpent which was to sting and poison the constitution." ${ }^{\prime 4}$ Stone rested his argument in part on the ratification debates in which "all those who opposed the government, dreaded this doctrine-those who advocated it, declared that it could not be resorted to-and all combined in opinion that it ought not to be tolerated." plied powers was to be accepted, all the framers need have done was write the preamble "and then said-Here is your constitution! Here is your bill of rights! Do these gentlemen require any thing more respecting the powers of Congress, than a description of the ends of government?" Stone also stressed the fact that the constitution was in writing. " $[\mathrm{T}]$ he end of all government is the public good-and if the means were left to legislation, all written compacts were nugatory." ${ }^{67}$ It was "the sober discretion of the legislature ... [that] was the very thing intended to be curbed and restrained by our constitution." 68

Another lawyer, James Jackson of Georgia, observed:

If the sweeping clause, as it is called, extends to vesting Congress with such powers, and necessary and proper means are an indispensable implication in the sense advanced by the advocates of the bill, we shall soon be

${ }^{62}$ Id. at 1951.

${ }^{63}$ Id.

${ }^{64} 14$ Documentary History OF the First Federal Congress 4 March 1789-3 March 1791 , supra note 36 , at 424 .

"Id.

${ }^{66} I d$. at 425 .

${ }^{67} I d$.

${ }^{68} I d$. 
in possession of all possible powers, and the charter under which we sit will be nothing but a name.

Representative William Giles of Virginia defined necessary as "that mean without which the end could not be produced." the suggestion that, "necessary, as applicable to a mean to produce an end, should be construed so as to produce the greatest possible quantum of public utility."

[That definition], if pursued, will be found to teem with dangerous effects, and would justify the assumption of any given authority whatever.

Terms are to be so construed as to produce the greatest degree of public utility. Congress are to be the judges of this degree of utility. This utility, when decided on, will be the ground of constitutionality. Hence, any measure may be proved constitutional, which Congress may judge to be useful. These deductions would suborn the Constitution itself, and blot out the great distinguishing characteristic of the free Constitutions of America, as compared with the despotic Governments of Europe, which consist in having the boundaries of governmental authority clearly marked out and ascertained. ${ }^{72}$

In other words, "[i]f expediency constituted constitutionality; the House judged of the expediency; then every measure they could possibly enter into would be ipso facto constitutional: And what would then be the weight it was intended that the constitution should have; and where were its limits?"73

In the executive branch, President Washington solicited the views of Attorney General Edmond Randolph, Secretary of State Thomas Jefferson, and Secretary of the Treasury Alexander Hamilton on the measure's constitutionality. A few days after the close of debate in Congress, Randolph and Jefferson conveyed their formal opinions to the President that the bill was unconstitutional largely for the same reasons enunciated by Madison. Randolph, who had served as a delegate to the Constitutional Convention from Virginia, wrote, "let it be propounded as an eternal question to those who build new powers on this clause, whether the latitude of construction, which they arrogate will not terminate in an unlimited power in Congress."74

In his formal opinion, Jefferson drew the same distinction as Madison had between necessity and convenience:

${ }^{69} 1$ ANNALS OF CONG. 1967 (Joseph Gales ed., 1791) (emphasis added).

${ }^{70}$ Id. at 1993.

${ }^{71} I d$.

${ }^{72} I d$.

78 DOCumentary History of THE First Federal Congress 4 March 1789-3 March 1791, supra note 36 , at 449 .

${ }^{74}$ Opinion of Edmund Randolph, Attorney General of the United States, to President Washington (Feb. 12, 1791), reprinted in LEGISLATIVE AND DOCUMENTARY HISTORY OF THE BANK OF THE UNITED STATES, at 86, 89 (M. St. Clair Clarke \& D.A. Hall eds., Augustus M. Kelley 1967) (1832) [hereinafter HISTORY OF THE BANK]. 
[T] he constitution allows only the means which are "necessary," not those which are merely convenient for effecting the enumerated powers. If such a latitude of construction be allowed to this phrase, as to give any non enumerated power, it will go to every one; for there is no one, which ingenuity may not torture into a convenience, in some way or other, to some one of so long a list of enumerated powers: it would swallow up all the delegated powers.... Therefore it was that the constitution restrained them to the necessary means; that is to say, to those means, without which the grant of the power would be nugatory.

Jefferson then allowed that "[p]erhaps, indeed, bank bills may be a more convenient vehicle than treasury orders." ${ }^{76}$ Despite this, "a little difference in the degree of convenience cannot constitute the necessity, which the constitution makes the ground for assuming any non enumerated power." 77

\section{As Madison summarized their argument:}

[the construction of power exercised by the bank bill] was condemned by the silence of the Constitution; was condemned by the rule of interpretation arising out of the Constitution; was condemned by its tendency to destroy the main characteristic of the Constitution; was condemned by the expositions of the friends of the Constitution, whilst depending before the public; was condemned by the apparent intention of the parties which ratified the Constitution; was condemned by the explanatory amendments proposed by Congress themselves to the Constitution; and he hoped it would receive its final condemnation by the vote of this House.

It did not.

\section{B. "Necessary" Means "Convenient": Hamilton and Marshall}

A week after Randolph and Jefferson issued their opinions, Hamilton, who had initially proposed the creation of the bank, defended the constitutionality of his proposal. As part of his very lengthy opinion, he offered an alternative interpretation of the term "necessary." According to both the "grammatical" and "popular" sense of the term,

necessary often means no more than needful, requisite, incidental, useful, or conducive to. It is a common mode of expression to say, that it is necessary for a government or a person to do this or that thing, when nothing more is intended or understood than that the interest of the Government

${ }^{75}$ Opinion of Thomas Jefferson, Secretary of State, on the Same Subject (Feb. 15, 1791), reprinted in HISTORY OF THE BANK, supra note 74, at 93.

${ }^{76}$ Id.

77 Id.

781 ANNALS OF CONG. 1952 (Joseph Gales ed., 1791). 
or person require, or will be promoted by, the doing of this or that thing.

Hamilton maintained that "[t] he whole turn of the clause containing it, indicates that it was the intent of the convention, by that clause, to give a liberal latitude to the exercise of the specified powers." ${ }^{80}$ Hamilton wrote:

[To adopt Jefferson's (and Madison's) interpretation] would be to depart from its obvious and popular sense, and to give it a restrictive operation; an idea never before entertained. It would be to give it the same force as if the word absolutely, or indispensably, had been prefixed to it.

Such a construction would beget endless uncertainty and embarrassment. The cases must be palpable and extreme, in which it could be pronounced with certainty, that a measure was absolutely necessary; or one, without which the exercise of a given power would be nugatory.

Hamilton also responded to the argument that a broad construction of this power would undermine the enumerated powers scheme. His argument highlights the distinction between interpretation and construction.

The same thing has been said, and may be said, with regard to every exercise of power, by implication or construction. The moment the literal meaning is departed from, there is a chance of error and abuse: and yet an adherence to the letter of its powers would at once arrest the motion of Government .... .

The truth is, that difficulties on this point are inherent in the nature of the federal constitution. They result inevitably from a division of legislative power. The consequence of this division is, that there will be cases clearly within the power of the National Government, others, clearly without its power; and a third class, which will leave room for controversy and difference of opinion, and concerning which a reasonable latitude of judgment must be allowed.

In evaluating his argument, it is perhaps worth remembering that Hamilton had four years earlier proposed to the Constitutional Convention a scheme of consolidated government in which the legislature of the United States would have been given "power to pass all laws whatsoever," 83 subject only to a nonoverridable veto power by the

${ }^{79}$ Opinion of Alexander Hamilton, on the Constitutionality of a National Bank (Feb. 23, 1791), reprinted in HISTORY OF THE BANK, supra note 74, at 97-98.

$I d$. at 98.

${ }^{81} \mathrm{Id}$.

82 Id. at 99.

83 1 THE ReCORDS OF THE FEderal CONVENTION OF 1787, at 291 (Max Farrand ed., rev. ed. 1966) (Madison quoting Hamilton). Although several different versions of Hamilton's proposal were recorded, none of these reports apparently differs on this aspect of his proposal. 3 $i d$. at 617-19 (describing the "considerable differences" of the versions of Hamilton's proposal with no mention of any variation on his proposed grant of power to the legislature to "pass all laws whatsoever"). 
supreme executive authority. He contemplated no enumeration of powers or allocation of powers between state and national governments. Hamilton introduced his plan in a lengthy speech to the convention, immediately after which the convention adjourned without discussion. It was never explicitly considered thereafter. Later the convention rejected the somewhat more qualified language proposed by Gunning Bedford of Delaware that would have given Congress power "to legislate in all Cases for the general Interests of the Union, and also in those Cases to which the States are separately incompetent, or in which the Harmony of the United States may be interrupted by the Exercise of individual Legislation." ${ }^{, 84}$

In the bank dispute, Hamilton, as the behind-the-scenes leader of the fledgling "Federalist" party that dominated Congress, gained the crucial support of the esteemed Washington and prevailed on the bank. ${ }^{85}$ Congress enacted the bank bill over the objections of the congressmen noted above, and Washington signed it into law over the objections of Jefferson and Randolph. Still, though several members of Congress had argued that the bank was constitutional-and this position prevailed-we cannot entirely be sure whether this was because a majority in Congress rejected a narrow conception of necessity or because a majority of the members thought the bank met the more stringent standard put forward by Madison and others. ${ }^{86}$

The meaning of the "necessary and proper clause" was first considered by the Supreme Court in 1805 in the case of United States $v$. Fisher. ${ }^{87}$ In his opinion, Chief Justice John Marshall interpreted the Clause to give almost complete discretion to Congress. He said, "Congress must possess the choice of means, and must be empowered to use any means which are in fact conducive to the exercise of a power granted by the constitution." 88 But Marshall gave his fullest, most careful, and most well-known treatment of this Clause some thirty years after the ratification of the Constitution in McCulloch $v$. Maryland, ${ }^{89}$ a case involving the constitutionality of the legislation es-

${ }^{8+} 2$ id. at $131-32$.

${ }^{85}$ This controversy was among those that contributed to Jefferson (and Madison) eventually splitting from the Federalists and founding the competing "Republican" party. This party, dubbed "democrat" by the Federalists-a term of opprobrium-eventually took that name as its own and survives as the Democratic Party that exists today. The Federalist party eventually collapsed, was initially supplanted by the Whigs, and then by the abolitionist Republican partythe party we know by that name today. Until the twentieth century, the Democrats largely maintained their Jeffersonian commitment to "strict construction" of federal powers, with the Republicans favoring more expansive construction of those powers.

${ }^{86}$ Of course, a third possibility cannot definitively be disproved: the Federalist-dominated Congress knowingly exceeded its enumerated powers under the Constitution.

${ }^{87} 6$ U.S. (2 Cranch) 358 (1805).

${ }^{88}$ Id. at 396.

8917 U.S. (4 Wheat.) 316 (1819). 
tablishing a second national bank. In his 1819 opinion, still often cited by the Supreme Court, Marshall adopted, in some places almost word for word, the opinion Hamilton issued as Secretary of the Treasury.

In $\mathrm{McCulloch}$, Maryland had challenged the constitutionality of the bank by asserting a narrow conception of necessity:

But the laws which they are authorized to make, are to be such as are necessary and proper for this purpose. No terms could be found in the language, more absolutely excluding a general and unlimited discretion than these. It is not "necessary or proper," but "necessary and proper." The means used must have both these qualities. It must be, not merely convenient-fit-adapted-proper, to the accomplishment of the end in view; it must likewise be necessary for the accomplishment of that end. Many means may be proper, which are not necessary; because the end may be attained without them. The word "necessary," is said to be a synonyme of "needful." But both these words are defined "indispensably requisite," and, most certainly, this is the sense in which the word "necessary" is used in the constitution. To give it a more lax sense, would be to alter the whole character of the government as a sovereignty of limited powers. This is not a purpose for which violence should be done to the obvious and natural sense of any terms, used in an instrument drawn up with great simplicity, and with extraordinary precision.

Echoing Hamilton, Marshall rejected this argument adopting instead the meaning that Madison, Jefferson, and Maryland had posed as its opposite-"necessary" means convenient:

If reference be had to its use, in the common affairs of the world, or in approved authors, we find that [the word "necessary"] frequently imports no more than that one thing is convenient, or useful, or essential to another. To employ the means necessary to an end, is generally understood as employing any means calculated to produce the end, and not as being confined to those single means, without which the end would be entirely unattainable.

Marshall's textual and functional defense of this definition of "necessary" is well known to law students. Unlike Madison's bank speech, Marshall's opinion is a central part of every casebook on constitutional law.

Textually, Marshall contrasted the use of the term "necessary" in this Clause with the term "absolutely necessary" used in Article I, Sec-

Id. at $366-67$ (emphasis added).

Id. at 413-14.

${ }^{92}$ However, one casebook unconventionally leads with Madison's speech, placing it before both McCulloch and Marbury. See PAUl BREST ET AL., Processes OF CONSTITUTIONAL DECISIONMAKING: CASES AND MATERIALS 8-11 (4th ed. 2000). 
tion 10,99 arguing that it is "impossible to compare the sentence[s] ... without feeling a conviction that the convention understood itself to change materially the meaning of the word 'necessary,' by prefixing the word 'absolutely." "94 Thus, he argued it is a mistake, as a textual matter, to equate the term necessary with the term absolutely necessary, as the State of Maryland purportedly did. ${ }^{95}$ This argument has greatly impressed later interpreters.

Functionally, Marshall argued:

It must have been the intention of those who gave these powers, to insure, so far as human prudence could insure, their beneficial execution. This could not be done, by confiding the choice of means to such narrow limits as not to leave it in the power of congress to adopt any which might be appropriate, and which were conducive to the end .... To have declared, that the best means shall not be used, but those alone, without which the power given would be nugatory, would have been to deprive the legislature of the capacity to avail itself of experience, to exercise its reason, and to accommodate its legislation to circumstances.

Marshall's functional argument depends upon the fear that the national government will fail without the sort of discretionary powers that his interpretation allows. As important, it assumes that this openended grant of discretionary powers will not eventually undermine the enumerated powers scheme as Madison predicted.

He dismissed, almost casually, concerns about how such an openended grant of discretionary power squared with the theory of limited and enumerated powers.

This government is acknowledged by all, to be one of enumerated powers. The principle, that it can exercise only the powers granted to it, would seem too apparent, to have required to be enforced by all those arguments, which its enlightened friends, while it was depending before the people, found it necessary to urge; that principle is now universally admitted. But the question respecting the extent of the powers actually granted, is perpetually arising, and will probably continue to arise, so long as our system shall exist.

And, just as Madison had given examples of enumerated powers that were not left to implication, Marshall offered three examples of unenumerated powers that had already been implied, even though they were arguably not "indispensably necessary" to the accomplishment of some enumerated purpose: the implied powers to carry mail be-

${ }^{93}$ U.S. CONST. art. I, $\$ 10$, cl. 2 ("No State shall, without the Consent of the Congress, lay any Imposts or Duties on Imports or Exports, except what may be absolutely necessary for executing its inspection Laws ....").

${ }^{94}$ McCulloch, 17 U.S. at 414-15.

${ }^{95}$ In its brief, quoted above, the State of Maryland did not use this phrase, though it did use the phrase "indispensably requisite." Id. at 367.

${ }^{96}$ McCulloch, 17 U.S. at 415.

${ }^{97}$ Id. at 405 . 
tween post offices and along post roads, ${ }^{98}$ to punish any violations of its laws, ${ }^{99}$ and to require congressional oaths of office. ${ }^{100}$

There are any number of quite plausible responses to these examples that someone employing Jefferson and Madison's conception of necessity could make. The power to carry mail can surely be considered, in Madison's words, both requisite to and "incident to the nature" ${ }^{" 101}$ of the postal power. Similarly, the power to punish violations is clearly incident, if not identical, to the nature of the lawmaking power. For many, a legislative enactment with no sanctions for disobedience can hardly be called a law. In contrast, the power to require congressional oaths of office may well be inessential to the performance of government. ${ }^{102}$ Let candidates for office challenge their opponents to take such an oath or suffer the electoral consequences the way they now do with promises pledging term limits and no new taxes. If the inability to require congressional oaths is the price for holding Congress to its enumerated powers, a Madisonian might contend it is a price well worth paying. ${ }^{10}$

Although Madison, as President, had actually signed into law the bill establishing the national bank that Marshall upheld as constitutional, ${ }^{104}$ it is significant that Madison took immediate exception to

${ }^{98}$ Id. at 417 ("It may be said, with some plausibility, that the right to carry the mail, and to punish those who rob it, is not indispensably necessary to the establishment of a post-office and post-road.").

${ }^{99} I d$. ("The several powers of congress may exist, in a very imperfect state, to be sure, but they may exist and be carried into execution, although no punishment should be inflicted, in cases where the right to punish is not expressly given.").

${ }^{100} I d$. at 416 ("The power to exact this security for the faithful performance of duty, is not given, nor is it indispensably necessary.").

1011 ANNALS OF CONG. 1947 (Joseph Gales ed., 1791).

${ }^{102}$ A mandatory congressional oath might be considered a qualification for holding office in addition to those mandated by Article I, Sections 2 and 3, and thus beyond the powers of Congress to impose. See Powell v. McCormack, 395 U.S. 486 (1969) (limiting Congress to judging only the qualifications for membership enumerated in Article I, Section 2). On the other hand, an oath requirement might be considered a procedural rule within the powers of each house to determine for itself rather than a law. On either theory, an oath requirement is either permissible or impermissible independent of the Necessary and Proper Clause.

${ }^{103}$ Assuming Marshall was correct in claiming that a Madisonian conception of necessity would mean that a mandatory congressional oath to preserve, protect, and defend the Constitution lies outside the powers of Congress, a Madisonian might respond that a Congress that imposed such a requirement would be violating the terms of such an oath.

${ }^{104}$ Madison later justified his decision by citing the precedent established by the longstanding acquiescence to the claimed power as well as by the expediency of the bank: "A veto from the Executive, under these circumstances, with an admission of the expediency and almost necessity of the measure, would have been a defiance of all the obligations derived from a course of precedents amounting to the requisite evidence of the national judgment and intention." Letter from James Madison to Mr. Ingersoll (June 25, 1831), in 4 LETTERS AND OTHER WRITINGS OF JAMES MADISON, at 186 (London, R. Worthington 1884) (emphasis added) [hereinafter LETTERS]. Of course, Madison may well have been wrong constitutionally to have signed the bill. 
Marshall's opinion in McCulloch, renewing the argument he had made as a congressman nearly thirty years before:

[O]f most importance is the high sanction given to a latitude in expounding the Constitution, which seems to break down the landmarks intended by a specification of the powers of Congress, and to substitute, for a definite connection between means and ends, a legislative discretion as to the former, to which no practical limit can be assigned. ${ }^{10}$

Madison then acknowledged that the national economy is interconnected-a supposedly modern development unknown to the founders-and then rejected it as a basis for a latitudinarian interpretation of "necessary":

In the great system of political economy, having for its general object the national welfare, everything is related immediately or remotely to every other thing, and, consequently, a power over any one thing, if not limited by some obvious and precise affinity, may amount to a power over every other. Ends and means may shift their character at the will and according to the ingenuity of the legislative body. ${ }^{106}$

He commented further, "Is there a legislative power, in fact, not expressly prohibited by the Constitution, which might not, according to the doctrine of the court, be exercised as a means of carrying into effect some specified power?"107

Virginian John Taylor, a contemporary of Madison and Marshall, penned an entire book protesting the reasoning of $\mathrm{McCulloch}$. In Construction Construed, and Constitutions Vindicated, he argued that " $[t]$ here are two kinds of construction; one calculated to maintain, the other to corrupt or destroy the principles upon which governments are established." 108 "Necessities," he argued, "are, strictly, things unavoidable .... The plain question, divested of verbal evolutions, is, whether congress are invested with the supreme power of altering or mending the constitution, should they imagine it to be expedient?"109 When necessity is taken to mean expedient, "this mode of construction completely establishes the position, that congress may pass any internal law whatsoever in relation to things, because there is nothing with which, war, commerce and taxation may not be closely or remotely connected."

${ }^{105}$ Letter from James Madison to Judge Roane (Sept. 2, 1819), in 3 LETTERS, supra note 104, at 143 .

${ }^{106}$ Id. at 143-44 (emphasis added).

107 Id. at 144.

108 John TAYlor, Construction Construed and Constitutions Vindicated 21 (The Lawbook Exchange, Ltd. 1998) (1820).

${ }^{109}$ Id. at 169.

${ }^{110}$ Id. at 170. 
Taylor further objected to Marshall's repeated reliance on the concept of "sovereignty" to justify discretionary congressional power. ${ }^{111}$ He wrote:

I do not know how it has happened, that this word has crept into our political dialect.... Neither the declaration of independence, nor the federal constitution, nor the constitution of any single state, uses this equivocal and illimitable word ....

In fact, the term "sovereignty," was sacrilegiously stolen from the attributes of God, and impiously assumed by kings. Though they committed the theft, aristocracies and republicks have claimed the spoil.

Because sovereignty "is neither fiduciary nor capable of limitation," "1s Taylor believed it gave rise to the "new idea of 'sovereign servants,' [by which] our legislatures are converted into British parliaments, daily new-modelling the substance of our government, by bodies politick, exclusive privileges, pensions, bounties, and judicial acts, comprising an arbitrary power of dispensing wealth or poverty to individuals and combinations, at their pleasure."114

\section{So Who Was Right? Perhaps They All Were}

What was the prevailing meaning of the term "necessary" when the Constitution was enacted? This question is addressed at some length by Gary Lawson and Patricia Granger. ${ }^{115}$ They note that the 1755 and 1785 editions of Samuel Johnson's Dictionary of the English Language "define 'necessary' as '1. Needful; indispensably requisite. 2. Not free; fatal; impelled by fate. 3. Conclusive; decisive by inevitable consequence." 116 This definition explicitly includes the meaning attached to the term "necessity" by the State of Maryland in its brief. It does not include the terms "convenient or useful" which Marshall following Hamilton claimed to be a popular connotation of the term.

Nevertheless, although they abstain from a final position on the issue, Lawson and Granger express sympathy for Marshall's interpreta-

\footnotetext{
11 An example of Marshall's reliance can be found in his discussion of the people and sovereignty:

[W] hen, "in order to form a more perfect union," it was deemed necessary to change this alliance into an effective government, possessing great and sovereign powers, and acting directly on the people, the necessity of referring it to the people, and of deriving its powers directly from them, was felt and acknowledged by all.

McCulloch v. Maryland, 17 U.S. (4 Wheat.) 316, 404 (1819); Id. at 409 ("The original power of giving the law on any subject whatever, is a sovereign power.").

112 TAYLOR, supra note 108 , at 25-26.

113 Id. at 27.

114 Id. at 1-2.

${ }^{115}$ Gary Lawson \& Patricia B. Granger, The "Proper" Scope of Federal Power: A Jurisdictional Interpretation of the Sweeping Clause, 43 DUKE L.J. 267, 286-89 (1993).

Id. at 286.
} 
tion based on the usage of the term "necessary" in the Constitution itself. In particular, they concede that the contrast between the term "necessary" in the Sweeping Clause and the use of the term "absolutely necessary" in Article I, Section 10, Clause 2 "strongly suggests that 'necessary,' by itself, does not connote indispensability." "To this they add the language of Article II, Section 3 instructing "the President to recommend to Congress 'such Measures as he shall judge necessary and expedient." "118 If 'necessary' means 'indispensable," they contend, "it is hard to understand why it would be conjoined with a term like 'expedient,' which suggests only a minimal requirement of usefulness."

On the other hand, if "necessary" means merely "convenient or useful," as Hamilton and Marshall contended, it is hard to see what the term "necessary" adds to the term "expedient." From this standpoint, the meaning of "necessary and expedient" is as elusive as it is redundant. Perhaps this is why Marshall himself did not point to Article II, Section 3. Because it is equally incompatible with both meanings of "necessary," this passage does not help us distinguish between one meaning and the other.

What about Marshall's strongest textual argument-the contrast between "necessary" in the Necessary and Proper Clause, and the use of "absolutely necessary" in Article I, Section 10, Clause 2? Recall that Marshall said it was "impossible to compare the sentence ... without feeling a conviction, that the convention understood itself to change materially the meaning of the word 'necessary,' by prefixing the word 'absolutely."' 120 But a review of the Convention notes suggests considerably less deliberation on this choice.

The Necessary and Proper Clause emerged from the Committee on Detail and was left unmodified by the Committee on Style. In contrast, Article I, Section 10, Clause 2 was proposed from the floor by George Mason (who sat on neither committee) on the last day of deliberation and the very day that the Constitution was voted on and approved, Saturday, September 15. (It was written up and signed two days later on Monday, September 17.) Mason's eleventh hour proposal was adopted without debate in the midst of a host of last minute adjustments. This hardly suggests a deliberate change of meaning.

Moreover, Mason was seeking to qualify a previously agreed upon prohibition against the states imposing any imposts or duties without the consent of Congress. Mason's language carves out an exception to this prohibition by granting the states the power to levy only those

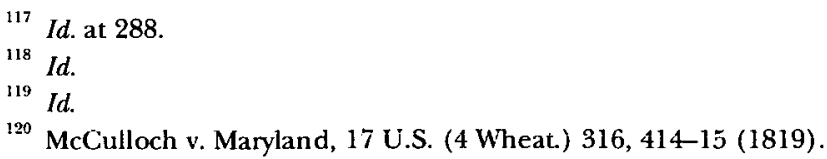


imposts that were necessary to pay for their inspection laws. Given that one of the prime reasons for the new Constitution was to prevent state interference with commerce, it is easy to understand why Mason would have proposed explicitly stringent restrictions on this exception.

Finally, Mason tended to favor the term "indispensably necessary" when speaking of grants of power and used the phrase frequently when speaking in the Virginia Ratification Convention. For example, while expressing his concerns about granting Congress the jurisdiction to govern the federal district, he expressed that he "was very willing to give them, in this as well as in all other cases, those powers which he thought indispensably necessary."21 Indeed the official Journal of the Convention records Mason's proposal that became Article I, Section 10, Clause 2 as reading "indispensably necessary" rather than "absolutely necessary."

All these factors, more than any deliberate distinction on the part of the Convention, explain the different usages in the two passages. Given its source, its last-minute nature, and its purpose, it is not at all clear that the choice of language "absolutely necessary" says much of anything about the meaning of the unqualified term "necessary" conjoined with "proper" in the Necessary and Proper Clause.

On the other hand, my previous references to the Convention debates have been offered to illustrate the public meaning of words used by the framers. In contrast, this evidence about the origin of the phrase "absolutely necessary" in Article I, Section 10 reflects the sort of "secret usage" foreclosed by original meaning originalism. If the intratextual comparison of "necessary" with "absolutely necessary" conveyed the public meaning that "necessary" in the Necessary and Proper Clause meant something less than "absolutely necessary," then evidence of how the two phrases came to be incorporated in the text is immaterial, provided that the legislative history was unknown, as it was, to the general public. Moreover, the phrase "indispensably necessary" was in common parlance at the time and was often used in the Convention and in other public statements. It would certainly have been possible for the Committee on Detail to have adopted that ter-

\footnotetext{
1213 DEBATES, supra note 15 , at 432.

${ }^{122}$ The Journal of the Federal Convention notes:

It was moved and seconded to substitute, for 1st part of clause 2d, section 10th, article 1st, the words,

"No state shall, without the consent of Congress, lay any imposts or duties on imports or exports, except what may be indispensably necessary for executing its inspection laws; and the net produce of all duties and imposts laid by any state on imports or exports shall be for the use of the treasury of the United States; and all such laws shall be subject to the revision and control of the Congress;" which passed in the affirmative.
}

Journal of the Federal Convention, in 1 DEBATES, supra note 15, at 313 (emphasis added). 
minology in the Necessary and Proper Clause had it wished to unambiguously convey that meaning.

Nevertheless, the intratextual comparison of "necessary" in the Necessary and Proper Clause with "absolutely necessary" in Article I, Section 10 overlooks a significant fact. Although Madison strongly opposed equating necessity with mere convenience, in his bank speech he also rejected the suggestion that "necessary" meant "indispensably necessary." Instead, he favored "a more liberal construction" because "very few acts of the legislature could be proved essentially necessary to the absolute existence of government.

Madison urged that the words be "understood so as to permit the adoption of measures the best calculated to attain the ends of government, and produce the greatest quantum of public utility." ${ }^{24}$ His reason was that "[i]n the Constitution, the great ends of government were particularly enumerated; but all the means were not, nor could they all be, pointed out, without making the Constitution a complete code of laws: some discretionary power, and reasonable latitude, must be left to the judgment of the legislature."125 For example, although the Constitution had given Congress the power to lay and collect taxes, "the quantum, nature, means of collecting, \&c., were of necessity left to the honest and sober discretion of the legislature." In his final remark on the constitutionality of the bank, Madison said, "no power could be exercised by Congress, if the letter of the Constitution was strictly adhered to, and no latitude of construction allowed, and all the good that might be reasonably expected from an efficient government entirely frustrated."

It seems then that Marshall-and most later commentators who rely solely upon his opinion in $\mathrm{McCulloch} \longrightarrow$ was considering a false dichotomy between mere "convenience" on the one hand and "absolute necessity" on the other. All parties to the first bank debate agreed that absolute necessity was not required, but at the same time all agreed that some degree of means-end fit was needed. As Hamilton stated in a passage of his opinion to Washington that is not usually emphasized, "[t]he relation between the measure and the end; between the nature of the mean employed towards the execution of a power, and the object of that power; must be the criterion of constitutionality; not the more or less of necessity or utility."128 In modern terms, a showing of necessity should neither be so "strict" that no statute can pass mus-

1294 DEBATES, supra note 15 , at 417 (statement of James Madison).

${ }^{124} \mathrm{Id}$.

${ }^{125} \mathrm{Id}$.

${ }^{126} I d$

${ }^{127} I d$. at $417-18$.

${ }^{128}$ Opinion of Alexander Hamilton, on the Constitutionality of a National Bank (Feb. 23, 1794), reprinted in HISTORY OF THE BANK, supra note 74, at 98 (emphasis altered). 
ter nor so lenient that any statute can pass. The appropriate "level of scrutiny" of a measure's necessity must lie somewhere in between. ${ }^{12}$

Even Marshall's opinion in McCulloch can be read as taking a more circumspect view of congressional power than is commonly taught. I have already mentioned Marshall's earlier interpretation of the Necessary and Proper Clause in United States v. Fisher, where he contended that "Congress must possess the choice of means, and must be empowered to use any means which are in fact conducive to the exercise of a power granted by the constitution." ${ }^{30}$ Here one indeed finds the very open-ended interpretation attributed by others to Marshall's opinion in McCulloch.

Yet in Fisher, as David Currie notes,

Marshall's rejection of a straw man had led him unjustifiably to the opposite extreme: that Congress has some latitude in the choice of means need not mean it may employ any "which are in fact conducive to the exercise of a power granted by the constitution." Virtually anything Congress might want to do could meet that criterion....

By contrast, Currie contends that, in McCulloch, Marshall was more careful than he had been in Fisher.

The means chosen must be "plainly" adapted to the end, not merely conducive to it; tenuous connections to granted powers will not pass muster. It must in addition be "appropriate," which implies some supervision of the reasonableness of the means. It must not, Marshall added in a later paragraph, be a mere "pretext ... for the accomplishment of objects not entrusted to the government." Finally, and most important, it must consist with the "spirit" as well as the letter of the constitution. ${ }^{132}$

Currie concludes, "In light of earlier statements in his opinion, the implication seems unmistakable: incidental authority must not be so broadly construed as to subvert the basic principle that Congress has limited powers." In other words, Marshall had come to sound more like Hamilton, who had admitted that a grant of power to make necessary laws was not unlimited after all; and also to sound more like Madison and Jefferson than is now usually appreciated.

Perhaps the modern disregard of Marshall's more limited conception of Congress's implied powers in McCulloch can be explained by

${ }^{129}$ For an amusing critique of these categories, see Michael Stokes Paulsen, Medium Rare Scrutiny, 15 CONST. COMMENT 397 (1998). For a proposed unified standard of review in Equal Protection cases, see Suzanne Goldberg, Equality Without Tiers, 77 S. CAL. L. REV. (forthcoming 2004).

${ }^{130}$ United States v. Fisher, 6 U.S. (2 Cranch) 358, 396 (1805).

191 David P. Currie, The Constitution in the Supreme Court: State and Congressional Powers, 18011835, 49 U. CHI. L. REV. 887, 931 (1982) (quoting John Marshall's opinion in Fisher, 6 U.S. (2 Cranch) at 396).

${ }^{132} I d$. at 932 (footnote omitted) (quoting Marshall's opinion in McCulloch v. Maryland, 17 U.S. (4 Wheat.) $316,423(1819)$ ).

193 Id. 
the fact that Marshall made little effort to apply his test to the case before him. Doing so "would have required a careful examination of the powers actually granted the Bank, of their relationship to the explicit powers of Congress, and of the degree to which they undermined the principle of limited federal powers." ${ }^{34}$ In the end, Currie agrees that "Marshall devoted most of his effort to demolishing the straw man of indispensable necessity and slid over the real question of the propriety of the Bank itself. Moreover, in so doing he seems to have undermined the exemplary test he had just laid down." ${ }^{135}$ This then became an open invitation for future generations to do the same.

[Marshall's] cavalier application of the test to the case before him, reinforced by his explicit refusal to examine the "degree of . . necessity" of any law "really calculated to effect any of the objects entrusted to the government," seemed to mean that the limits he had laid down should not be taken seriously. ${ }^{136}$

And they have not been.

\section{Judicial Deference and the Meaning of "Necessity"}

This evidence suggests that, while it is a mistake to equate "necessary" with "convenient," neither was it as stringent a standard as connoted by the terms "indispensably" or "absolutely" necessary. Instead, the original meaning of necessity creates the requirement of a degree of means-end fit somewhere between these two extremes. Considerations of constitutional construction also argue against a looser standard of "convenience."

Equating necessity with mere convenience or expediency-the view commonly, but perhaps mistakenly, attributed to Marshallwould make the application of this standard a matter of policy properly left to the discretion of the legislature. On the other hand, if one adopts the view of Jefferson and Madison that "necessary" means that a given law must be incidental and closely connected to an enumerated power, then this is a matter of constitutional principle and within the purview of the Courts to assess. Thus, the true debate is whether the original meaning of "necessary" was narrow enough to be enforced by courts or so open-ended that it instead became completely within the discretion of the legislature. If the Necessary and Proper Clause was generally thought justiciable, this further supports the

194 Id. at 933.

135 Id. at 933-34 (footnote omitted).

${ }^{136}$ Id. at 934 (alteration in original) (quoting Marshall's opinion in McCulloch, 17 U.S. (4 Wheat.) at 423). 
conclusion that the public meaning of the term "necessary" was not equated with mere convenience or utility.

There is some textual support for the proposition that this Clause, like all the other limits on congressional power, should be judicially enforceable. The first is the fact that the Clause says that laws shall be necessary and proper. In ordinary life, "shall" sometimes refers merely to a statement about what someone intends to do in the future. In the 1785 edition of A Dictionary of the English Language, ${ }^{137}$ Samuel Johnson noted that "[t]he explanation of shall, which foreigners and provincials confound with will, is not easy; and the difficulty is increased by the poets, who sometimes give to shall an emphatical sense of will." Instead, Johnson repeatedly equated "shall" with "must." Then as now, in legal discourse the term "shall" was nearly always a mandatory command. "As used in statutes, contracts, or the like, this word is generally imperative or mandatory." When the law creates discretion, it uses the word "may" instead. Johnson defined "may" as, "[t]o be at liberty; to be permitted; to be allowed." 139

The authors of the Constitution were very careful to use "shall" and "may" properly. This strongly suggests that the injunction, "to make all laws which shall be necessary and proper," was not discretionary on the part of the law-making authority to whom it is directed-Congress. It is mandatory, and like all other mandatory provisions, is presumptively enforceable by the other branches of government, including the courts.

Equally suggestive is the frequency with which the Constitution specifies the discretion it grants to particular actors indicating that, when unreviewable discretion was granted over an important matter, it was done explicitly. Article I, Section 3 stipulates that " $[t]$ he Senate shall have the sole Power to try all Impeachments." Article I, Section 5 says that "[e]ach House shall be the Judge of the Elections, Returns and Qualifications of its own Members" and that "[e]ach House shall keep a Journal of its Proceedings, and from time to time publish the same, excepting such Parts as may in their Judgment require Secrecy."142

197 SAMUEL JOHNSON, A DictionaRY Of THE ENGlish LANGUAGE (London, J.F. \& C. Rivington 6 th ed. 1785). All references to Johnson's dictionary that appear here are to this edition, which is the closest in time to the drafting of the Constitution. This edition was not paginated so page numbers cannot be provided.

138 BLACK'S LAW DICTIONARY 1541 (rev. 4th ed. 1968).

199 JOHNSON, supra note 137.

140 U.S. CoNST. art. I, $\S 3$, cl. 6 (emphasis added).

${ }^{141} I d ., \$ 5, \mathrm{cl}$. 1 (emphasis added).

142 Id., cl. 3 (emphasis added). 
Article I, Section 9 speaks of " $[\mathrm{t}]$ he Migration or Importation of such Persons as any of the States now existing shall think proper to admit." ${ }^{143}$

The textual contrast between these provisions and the wording of the Necessary and Proper Clause severely undermines Joseph Lynch's thesis that the Clause was so ambiguous that Congress was left "to determine whether, pursuant to that Clause, they could legislate in the general interests of the country or whether they could merely implement the specifically enumerated powers." ${ }^{144}$ To the contrary, a better presumption is that, where the Constitution grants unlimited discretion, it does so explicitly.

Although many powers are granted solely to one actor by use of the phrase, "shall have power," such as the pardon power of the President, ${ }^{145}$ without explicitly saying that the power is unreviewable, the Necessary and Proper Clause uses "shall" twice: once to say that "Congress shall have power... to make all laws" and again to state that, those laws "shall be necessary and proper." 146 Only Congress is granted the power to make laws, but a mandatory standard for law making is then imposed upon it.

Many examples where discretion is explicitly provided by the Constitution concern the application of a standard, not the allocation of power. Article II, Section 1 states that "[e]ach State shall appoint [Electors], in such Manner as the Legislature thereof may direct." ${ }^{14}$ Article II, Section 2 states that "Congress may by Law vest the Appointment of such inferior Officers, as they think proper." 148 Article II, Section 3 specifies that the President "shall from time to time give to the Congress Information of the State of the Union, and recommend to their Consideration such Measures as he shall judge necessary and expedient" and that "he may adjourn them to such Time as he shall think proper." Article V says that "Congress, whenever two thirds of both Houses shall deem it necessary, shall propose Amendments to this Constitution." 150

Congress is given no such discretion over the application of the standard supplied in the Necessary and Proper Clause. We need not imagine the outcry that such an expressed discretion would have engendered. Even in its absence, opponents of the Constitution protested that Congress was being given this discretion while its propo-

${ }^{143}$ Id., $\$ 9, \mathrm{cl} .1$ (emphasis added).

${ }^{144}$ LYNCH, supra note 26 , at 100.

${ }^{145}$ See U.S. CONST. art. II, $\$ 2$, cl. 1 ("The President. . . shall have Power to grant Reprieves and Pardons for Offenses against the United States, except in Cases of Impeachment.").

${ }^{146} I d$., art. I, $\$ 8$.

${ }^{14}$ Id., art. II, $\$ 1, \mathrm{cl} .2$ (emphasis added).

${ }^{148}$ Id., $\S 2$, cl. 2 (emphasis added).

${ }^{149}$ Id., $\$ 3$ (emphasis added).

${ }^{150} I d$., art. V (emphasis added). 
nents denied the charge repeatedly-a denial that would have been impossible in the face of discretionary language comparable to that found elsewhere in the text. This strongly suggests that, whatever meaning the Clause had, it must be one that is justiciable.

Although the justiciability of the Necessary and Proper Clause was not considered by the Constitutional Convention, where it received virtually no discussion, the issue did arise in ratification conventions. In Virginia, when discussing the sweeping clause, George Nicholas asked rhetorically, "[W] ho is to determine the extent of such powers?"151 To this he replied, "I say, the same power which, in all wellregulated communities, determines the extent of legislative powers. If they exceed these powers, the judiciary will declare it void, or else the people will have a right to declare it void." ${ }^{52}$

Madison himself raised the issue of justiciability in his second speech to Congress on the National Bank. To those who asserted that "necessary" meant merely expedient, he replied, "[W]e are told, for our comfort, that the Judges will rectify our mistakes. How are the Judges to determine in the case; are they to be guided in their decisions by the rules of expediency?"153 This statement should not be interpreted as a rejection of judicial review, but as a rejection of a standard of constitutionality that would preclude judicial review.

Years later in his critique of Marshall's opinion in McCulloch, Madison argued against an interpretation of "necessary" that takes the Clause outside the province of the courts, asking rhetorically, "does not the court also relinquish, by their doctrine, all control on the legislative exercise of unconstitutional powers?"154 Madison objected to interpreting "necessary" as merely expedient or convenient, in part, because doing so would place the matter "beyond the reach of judicial cognizance." dle could the court take hold of the case?"

Suppose Congress had expressly been given the power to pass "all laws that it shall think necessary and proper." One indication of how poorly received such wording would have been is illustrated by an interesting exchange that occurred during the debate over the National Bank between Representatives Michael Stone of Maryland and William Smith of South Carolina. Stone accused Smith of holding the view that "all our laws proceeded upon the principle of expediencythat we were the judges of that expediency-as soon as we gave it as

1513 DEBATES, supra note 15 , at 443

152 Id.

1531 ANNALS OF CONG. 2010 (Joseph Gales ed., 1791).

${ }^{154}$ Letter from James Madison to Judge Roane (Sept. 2, 1819), in 3 LETTERS, supra note 104, at 144 .

155 Id.

${ }^{156} I d$. 
our opinion that a thing was expedient, it became constitutional."157 To this, Smith revealingly replied:

He had never been so absurd as to contend, as the gentleman had stated, that whatever the Legislature thought expedient, was therefore constitutional. He had only argued that, in cases where the question was, whether a law was necessary and proper to carry a given power into effect, the members of the Legislature had no other guide but their own judgment, from which alone they were to determine whether the measure proposed was necessary and proper.... That, nevertheless, it was still within the province of the Judiciary to annul the law, if it should be by them deemed not to result by fair construction from the powers vested by the Constitution. ${ }^{158}$

Although Smith voted for the Bank Bill, at the same time he rejected the "absurd" accusation that Congress was the sole judge of a measure's necessity and propriety. By insisting on the appropriateness of judicial review, Smith was affirming a conception of necessity that was narrow enough to be justiciable. Smith's affirmation of judicial review also indicates that the bill's passage need not have represented an acceptance of the sort of open-ended discretion in Congress that has come to be associated with McCulloch. Instead, a majority of Congress may well have embraced the stricter meaning of "necessary" and simply concluded, rightly or wrongly, that the bank's purpose met this more demanding standard.

That exercises of power under the Necessary and Proper Clause were thought subject to judicial review was also assumed by the author of the first scholarly work on the Constitution. St. George Tucker was a professor of law at the College of William and Mary, one of the leading judges of the General Court in Virginia, and the American editor of Blackstone's Commentaries, the most influential and authoritative legal work of the period. In the 1803 edition of the Commentaries, he attached an appendix discussing the meaning of the United States Constitution. This work was drawn from the notes of his lectures given throughout the 1790 s, contemporaneous with the earliest years of the Constitution.

Tucker's account of the Necessary and Proper Clause is nearly identical to that of Madison's and Jefferson's, as well as to the views expressed in the ratification conventions. In the appendix to Volume One of Blackstone's Commentaries, he observed:

The plain import of this clause is, that congress shall have all the incidental or instrumental powers, necessary and proper for carrying into execution all the express powers; whether they be vested in the government of the United States, more collectively, or in the several departments, or officers thereof. It neither enlarges any power specifically

\footnotetext{
${ }^{157} 1$ ANNALS OF CONG. 1983 (Joseph Gales ed., 1791).

${ }^{158}$ Id. at 1988 (emphasis added).
} 
granted, nor is it a grant of new powers to congress, but merely a declaration, for the removal of all uncertainty, that the means of carrying into execution those otherwise granted, are included in the grant.

Tucker was gravely concerned about the use of the Clause to justify an unwarranted expansion of congressional power:

But, notwithstanding this remarkable security against misconstruction, a design has been indicated to expound these phrases in the constitution, so as to destroy the effect of the particular enumeration of powers, by which it explains and limits them, which must have fallen under the observation of those who have attended to the course of public transactions.

In a footnote to the preceding statement, he added, "[w]itness, the act for establishing a bank."

Tucker then offered the following method of construing the Clause and other powers of Congress:

Whenever, therefore, a question arises concerning the constitutionality of a particular power; the first question is, whether the power be expressed in the constitution? If it be, the question is decided. If it be not expressed, the next enquiry must be, whether it is properly an incident to an express power, and necessary to it's [sic] execution. If it be, it may be exercised by congress. If it be not, congress cannot exercise it . . . .

He contended:

[T] his construction of the words 'necessary and proper,' is not only consonant with that which prevailed during the discussions and ratifications of the constitution, but is absolutely necessary to maintain their consistency with the peculiar character of the government, as possessed of particular and defined powers, only; not of the general and indefinite powers vested in ordinary governments.

This construction would constrain members of Congress through their oaths and is "indispensably necessary to support that principle of the constitution, which regards the judicial exposition of that instrument, as the bulwark provided against undue extension of the

${ }^{159}$ St. George Tucker, Appendix, in 1 William BlackSTONe, COMMENTARIES: With NOTES OF REFERENCE TO THE CONSTITUTION AND LAWS OF THE FEDERAL GOVERNMENT OF THE UNITED STATES AND OF THE COMMONWEALTH OF VIRGINIA 287 (1803).

${ }^{160} I d$.

${ }^{161} I d$. at $n . *$ The footnote continues with further examples: "the act authorising the president to appoint officers to volunteer corps of militia; the act declaring that a paper not stamped agreeably thereto, shall not be admitted as evidence in a state court; the alien and sedition laws, \&c." Id. The note concludes with statements from the report on the committee of the general assembly of Virginia, on the alien and sedition laws, Jan. 20, 1800: "not to multiply proofs on this subject, it may be sufficient to refer to the debates of the federal legislature, for several years, in which arguments have, on different occasions, been drawn with apparent effect from these phrases, in their indefinite meaning." Id.

${ }^{162} I d$. at 288.

${ }^{169} I d$. (citing report of the committee on the general assembly of Virginia, on the alien and sedition laws, Jan. 20, 1800, to support his proposition). 
legislative power."164 Like Madison, Tucker affirmed that this standard was within the competence of judges to apply. Tucker explained:

If it be understood that the powers implied in the specified powers, have an immediate and appropriate relation to them, as means, necessary and proper for carrying them into execution, questions on the constitutionality of laws passed for this purpose, will be of a nature sufficiently precise and determinate, for judicial cognizance and control. If on the one hand congress are not limited in the choice of the means, by any such appropriate relation of them to the specified powers, but may use all such as they may deem capable of answering the end, without regard to the necessity, or propriety of them, all questions relating to means of this sort must be questions of mere policy, and expediency, and from which the judicial interposition and control are completely excluded. ${ }^{165}$

Although David Currie suggests a more restrictive interpretation of $M c C u l l o c h$ than the decision was given by its critics at the time, it is the latitudinarian gloss on the meaning of "necessary" that survives to this day largely unchallenged. While Marshall's fear of impotent government remains a matter of speculation (because he got his way), history seems to have borne out Madison's expressed concern for the integrity of the enumerated powers scheme. With rare exception, the enumeration of powers has largely been vitiated as a limitation on the scope of the national government, due in no small measure to the influence of Justice Marshall's opinion in McCulloch. As Stephen Gardbaum has observed:

McCulloch is ... one of the handful of foundational decisions of the Supreme Court that are automatically cited as original sources for the propositions of constitutional law that they contain. But McCulloch has the further (and even rarer) distinction of being treated as providing a full and complete interpretation of a particular clause of the Constitution. Analysis of the Necessary and Proper Clause has historically begun and ended with $\mathrm{McCulloch} . .$. .

Therefore, it is supremely ironic that, like the other leading figures already discussed, John Marshall also insisted that the courts should not cede unlimited discretion to Congress. In a practice that by today's standards would be thought bizarre, Marshall responded to the torrent of condemnation with a pseudonymously published defense of his own opinion in McCulloch. Writing as "A Friend of the Constitution," he took pains to emphasize that his interpretation of the Necessary and Proper Clause did not cede a complete discretion to Congress:

\footnotetext{
${ }^{164} I d$.

${ }^{165}$ Id. at 288-89 (emphasis added).

${ }^{166}$ Gardbaum, supra note 7, at 814.
} 
In no single instance does the court admit the unlimited power of congress to adopt any means whatever, and thus to pass the limits prescribed by the constitution. Not only is the discretion claimed for the legislature in the selection of its means, always limited in terms, to such as are appropriate, but the court expressly says, "should congress under the pretext of executing its powers, pass laws for the accomplishment of objects, not entrusted to the government, it would become the painful duty of this tribunal ... to say that such an act was not the law of the land. ${ }^{167}$

True, Madison expressed his doubts about Marshall's assertion of a continued power of judicial nullification:

But suppose Congress should, as would doubtless happen, pass unconstitutional laws, not to accomplish objects not specified in the Constitution, but the same laws as means expedient, convenient, or conducive to the accomplishment of objects intrusted to the government; by what handle could the court take hold of the case? ${ }^{168}$

Although Madison's gloomy prediction proved prescient, Marshall had, nevertheless, conceded the point that the judiciary should maintain some control over the exercise of congressional power under the Necessary and Proper Clause.

\section{THE MEANING OF "PROPER": MEANS AND ENDS}

Marshall's affirmation that congressional powers are limited to those means "such as are appropriate"169 emphasizes a portion of the Necessary and Proper Clause usually overlooked by those who assert that it is not justiciable-the meaning of the term "proper." In what respect could a measure that was shown to be truly necessary to the effectuation of an enumerated purpose ever be improper? Would a meaningful means-end scrutiny of the necessity of a restriction on the people's liberties make an assessment of its propriety superfluous?

One thing that stands out from the records of the Constitutional Convention is how frequently the term "necessary" was paired with "proper" (or "unnecessary" with "improper") in contexts suggesting that each term has a distinct meaning. For example, when Rufus King of Massachusetts objected to one of the rules of the Convention "authorising any member to call for the yeas \& nays and have them entered on the minutes," he "urged that as the acts of the Convention were not to bind the Constituents, it was unnecessary to exhibit this evidence of the votes; and improper as changes of opinion would be

${ }^{167}$ John Marshall, A Friend of the Constitution, ALEXANDRIA GAZETTE, July 5, 1819, reprinted in JOHN MARShaLl's DEFENSE OF MCCULLOCH V. MARYLAND 186-87 (Gerald Gunther ed., Stanford University Press 1969) [hereinafter JOHN MARSHALL'S DEFENSE] (emphasis added).

${ }^{168}$ Letter from James Madison to Judge Roane (Sept. 2, 1819), in 3 LETTERS, supra note 105, at 144 .

${ }^{169}$ Marshall, supra note 167, at 187 (emphasis added). 
frequent in the course of the business \& would fill the minutes with contradictions." 170

Although the distinction between "necessary" and "proper" resonates throughout the convention, it is often hard to figure out its meaning. Perhaps the clearest example is when Madison objected to the requirement that, to be a Senator one must have first been a citizen for fourteen years. While he agreed with some citizenship requirement,

[h] e thought any restriction however in the Constitution unnecessary, and improper. [U] nnecessary; because the [National Legislature] is to have the right of regulating naturalization, and can by virtue thereof fix different periods of residence as conditions of enjoying different privileges of Citizenship: Improper; because it will give a tincture of illiberality to the Constitution: because it will put out of the power of the [National] Legislature even by special acts of naturalization to confer the full rank of Citizens on meritorious strangers \& because it will discourage the most desireable class of people from emigrating to the U.S. ${ }^{171}$

Madison's use of "unnecessary" here is relatively clear. The end can be accomplished by other less potentially intrusive means. His use of "improper" is harder to see, but seems to consist of a kind of wrong or injustice ("a tincture of illiberality") coupled with the idea that it was "properly" within the jurisdiction of the legislature to make this kind of decision. The injustice of such a restriction is underscored by his comment that, if the Constitution is successful in its aim, "great numbers of respectable Europeans: men who love liberty and wish to partake its blessings, will be ready to transfer their fortunes hither. All such would feel the mortification of being marked with suspicious incapacitations though they [should] not covet the public honors." ${ }^{172}$

Gary Lawson and Patricia Granger made an extensive examination of sources from the founding era and concluded that the following "jurisdictional" meaning of proper covers most instances of its actual use:

In view of the limited character of the national government under the Constitution, Congress's choice of means to execute federal powers would be constrained in at least three ways: first, an executory law would have to conform to the "proper" allocation of authority within the federal government; second, such a law would have to be within the "proper" scope of the federal government's limited jurisdiction with respect to the retained prerogatives of the states; and third, the law would have to be within the "proper" scope of the federal government's limited jurisdiction with respect to the people's retained rights. In other

\footnotetext{
${ }^{170}$ MADISON, supra note 13 , at 25 (emphasis added).

171 Id. at 419 .

${ }^{172} I d$.
} 
words, . . . executory laws must be consistent with principles of separation of powers, principles of federalism, and individual rights.

In sum, for a law to be "proper" it must not only be necessary, it must also be within the jurisdiction of Congress. This propriety of jurisdiction is determined in at least three ways: (1) according to principles of separation of powers, (2) according to principles of federalism, and (3) according to the background rights retained by the people. Given the importance of natural rights to constitutional legitimacy in the absence of unanimous consent, ${ }^{174}$ let me focus on the third element: laws are improper when they violate the background rights retained by the people.

If necessity is taken to mean "convenient," it is easy to see how an exercise of so discretionary a power could violate the background rights retained by the people, though taking seriously this problem reintroduces-under the rubric of "propriety" - many of the difficulties Marshall argued attach to a strict construction of necessity. Adopting a Madisonian conception of necessity, however, raises a potential difficulty: if a restriction of liberty is shown to be a truly necessary means of executing an enumerated power or end, in what way can it be considered an "improper" infringement on these background rights? Have not the people surrendered to the national government the powers that were enumerated in Article I and any right inconsistent with the exercise of such powers?

The answer to this rhetorical question is not as obvious as some may think. The appropriate legal construct is not the surrender of rights to a master, but the delegation of powers to an agent. As Marshall himself wrote, "It is the plain dictate of common sense, and the whole political system is founded on the idea, that the departments of government are the agents of the nation, and will perform, within their respective spheres, the duties assigned to them." ${ }^{175}$ When a principal engages an agent, the agent can be empowered to act on behalf of and subject to the control of the principal at the same time the principal retains all of his rights. ${ }^{176}$ For example, a principal can empower the agent to sell the principal's car while retaining the right to sell it himself.

The fact that a principal retains rights is one reason that agents can be sued for failing to act on their principal's behalf or refusing to

\footnotetext{
${ }^{178}$ Lawson \& Granger, supra note 115, at 297.

${ }^{174}$ See generally Randy E. Barnett, Constitutional Legitimacy, 103 CoLUM. L. REV. 111 (2003).

${ }^{175}$ John Marshall, A Friend of the Constitution, ALEXANDRIA GAZETTE, July 15, 1819, reprinted in JOHN MARSHALL'S DEFENSE, supra note 167, at 211.

${ }^{176}$ See Randy E. Barnett, Squaring Undisclosed Agency Law With Contract Theory, 75 CAL. L. REV. 1969,1981 (1987) ("A principal who authorizes his agent to so act 'on his behalf' consensually empowers the agent to exercise certain rights that the principal alone would normally exercise.").
} 
conform their actions to their principal's exercise of control. In normal agency relationships, the empowerment of an agent to act on the principal's behalf does not make the agent the sole judge of whether she is acting within the scope of her agency, as the discretionary conception of necessity seems to do. Moreover, the fact that some rights are inalienable suggests that those who purport to exercise them on behalf of another need to justify their assumption of such power. ${ }^{177}$

To see how a necessary law could still be improper, consider an example offered by Madison in his speech explaining his proposed amendments to the Constitution that became the Bill of Rights.

The General Government has a right to pass all laws which shall be necessary to collect its revenue; the means for enforcing the collection are within the direction of the Legislature: may not general warrants be considered necessary for this purpose ...? If there was reason for restraining the State Governments from exercising this power, there is like reason for restraining the Federal Government.

In other words, although using general warrants might "be considered necessary," their use would still be improper and unconstitutional. Nor would it be fair to conclude from this quote that impropriety was limited to violations of express restrictions of power. There is little doubt that the use of general warrants would have been considered improper during the two-year hiatus between the ratification of the Constitution and the amendments. The impropriety of using general warrants stems from the need to protect a person and his property from unreasonable searches and seizures. ${ }^{179}$

Another example of how the Necessary and Proper Clause confines Congress to using only those necessary means that are also proper was offered by St. George Tucker: "If, for example, congress were to pass a law prohibiting any person from bearing arms, as a means of preventing insurrections, the judicial courts, under the con-

177 See Randy E. Barnett, Contract Remedies and Inalienable Rights, 4 SOC. PHIL. \& POL'Y 179, 185-95 (1986) (defining inalienable rights and providing four reasons why some rights are inalienable).

178 ANNALS OF CONG. 456 (Joseph Gales ed., 1789).

${ }^{179}$ A "general warrant" was one that did not specify the place or person to be searched and thus authorized government agents to search whom and where they pleased. Search warrants immunized a government agent from liability in trespass. The later rise of "sovereign immunity" made warrants less necessary for this purpose, and greatly undermined the incentive of law enforcement to comply with the warrant requirement. At present, the principal consequence of a warrantless illegal search is the suppression of evidence, which only helps the guilty. The original system of immunization from tort liability only when a warrant was obtained also helped the innocent and provided a greater deterrent against improper searches. See generally Randy E. Barnett, Resolving the Dilemma of the Exclusionary Rule: An Application of Restitutive Principles of Justice, 32 EMORY L.J. 937 (1983) (examining the costs of the exclusionary rule and the benefits of the alternative restitutive model). 
struction of the words necessary and proper, here contended for, would be able to pronounce decidedly upon the constitutionality of these means." 180 Giving Congress the power to choose any means it deems necessary would improperly expand its power to invade the rights retained by the people-in this case the enumerated right to keep and bear arms.

But if congress may use any means, which they choose to adopt, the provision in the constitution which secures to the people the right of bearing arms, is a mere nullity; and any man imprisoned for bearing arms under such an act, might be without relief; because in that case, no court could have any power to pronounce on the necessity or propriety of the means adopted by congress to carry any specified power into complete effect.

These are examples of improper means thought necessary to accomplish an enumerated or "proper" end. Even a necessary means of pursuing a delegated power can "inappropriately" restrict the exercise of a right retained by the people. According to this view, although it may be necessary and proper to regulate a genuine exercise of liberty, it is inappropriate to prohibit its exercise altogether. ${ }^{182}$ Whether or not a restriction on liberty is "inappropriate" would depend, therefore, not only on the degree of means-end fit, but on whether the measure is a regulation or a prohibition. While wrongful action can properly be prohibited, it would be improper to prohibit or deliberately subvert or discourage, as opposed to regulate and facilitate, rightful conduct. ${ }^{183}$

A law would also obviously be improper if enacted to accomplish an improper end. The powers enumerated in the Constitution, such as the power to raise and support armies, to establish post offices, or to grant monopolies for limited periods to authors can be viewed as objects or ends that are deemed proper by the text. Such powers are "locked in" along with the other provisions of the written Constitution as a matter of positive law, whether or not they are truly among the proper ends of government. ${ }^{184}$ In this respect, some ends-scrutiny is foreclosed by a written Constitution containing enumerated powers.

${ }^{180}$ Tucker, supra note 159, at 289 (emphasis added).

181 Id. (emphasis added). Notice also that Tucker assumes here that the right of the people to keep and bear arms is an individual right that would restrict the disarmament of "any man" without reference to whether he was actively serving in the militia at the time.

${ }^{182}$ In contrast, if the action is an exercise of license (as opposed to liberty) it can be prohibited altogether.

${ }^{183}$ I discussed the distinction between regulation and prohibition at greater length in Barnett, Original Meaning, supra note 2, in the context of Congress's power to "regulate trade."

${ }^{184}$ Laws passed pursuant to an enumerated power that is actually improper, though authorized by positive law, may be as illegitimate as the powers created by the Fugitive Slave Clause of Article IV. Though a judge committed to a written constitution would not be free to declare such laws unconstitutional, their commands may not bind in conscience. 
Nevertheless, judicial scrutiny of ends would be needed and warranted (or necessary and proper) when Congress purported to be pursuing an enumerated end, but is actually pursuing a purpose other than those included in the enumeration of its powers. A law actually enacted for a purpose or end that was not among those enumerated would exceed its jurisdiction under the Constitution and be improper regardless of the means it employed. Such a law would be, in the words of John Marshall in McCulloch, a mere "pretext ... for the accomplishment of objects not intrusted to the government."

If Congress were to enact such a law, Marshall insisted, "it would become the painful duty of this tribunal ... to say, that such an act was not the law of the land." Wholly apart from the need to assess a measure's necessity, Congress cannot be the sole judge of whether it is acting within its powers because that would give it license to pursue objects or ends that are beyond its powers. In other words, an otherwise necessary law can still be improper if it employs improper means, such as by prohibiting or discouraging rather than regulating and facilitating rightful conduct, or if it is intended by Congress to accomplish an improper end, such as an end not enumerated in the Constitution.

\section{CONCLUSION}

After the Preamble, the very first sentence of the Constitution reads: "All legislative Powers herein granted shall be vested in a Congress of the United States ...." tionality of a federal law must begin by determining whether Congress acted within one of the enumerated powers it is granted in the Constitution. Identifying the meaning of an enumerated power, however, is only part of what is required to determine whether Congress is within its constitutionally delegated powers. We must also reach a conclusion about the meaning of the Necessary and Proper Clause.

The meaning we attach to that Clause not only determines the scope of congressional power-it determines the degree of deference that courts owe a congressional judgment that it is acting within its powers. If you take the view attributed to Marshall that "necessary" means merely convenient or useful, then courts are generally un-

\footnotetext{
${ }^{185}$ McCulloch v. Maryland, 17 U.S. (4 Wheat.) 316, 423 (1819).

${ }^{186}$ Id. One way to understand the difference between Marshall and Madison is that, while Marshall would limit judicial nullification to ends-scrutiny, Madison-and I think Hamilton as well-would also permit scrutiny of the means chosen in pursuit of a proper end.

${ }^{187}$ U.S. CONST. art. I, $\$ 1$ (emphasis added). For this reason, if no other, the Tenth Amendment to the Constitution is superfluous.
} 
qualified to second-guess a congressional determination of expediency. On the other hand, if the Clause requires (1) a showing of means-ends fit-as per Madison, Jefferson and even Hamiltontogether with a showing that (2) the means chosen do not prohibit the rightful exercise of freedom (or violate principles of federalism or separation of powers) and (3) Congress's claim to be pursuing an enumerated end is not a pretext for pursuing other ends not delegated to it (as per Marshall in McCulloch), then an inquiry into each of these issues is clearly within the competence of courts. The meaning one attributes to the terms "necessary" and "proper" is, therefore, enormously important because the nature and scope of judicial review turns on which meaning one adopts. The evidence presented in this Article should be significant to the many who believe that the answer to this interpretive question turns in whole, or in part, on the original meaning of the Necessary and Proper Clause. 